\title{
Gold Nanoparticles Bearing an $\alpha$-Lipoic Acid-based Ligand Shell: Synthesis, Model Complexes and Studies Concerning Phosphorescent Platinum(II)-Functionalisation
}

Ulrich Siemeling ${ }^{\mathrm{a}}$, Frauke Bretthauer ${ }^{\mathrm{a}}$, Clemens Bruhn ${ }^{\mathrm{a}}$, Tim-Patrick Fellinger ${ }^{\mathrm{b}}$, Wah-Leung Tong ${ }^{\mathrm{c}}$, and Michael C. W. Chan ${ }^{\mathrm{c}}$

${ }^{a}$ Institut für Chemie, Universität Kassel, Heinrich-Plett-Straße 40, 34132 Kassel, Germany

${ }^{\mathrm{b}}$ Max-Planck-Institut für Kolloid- und Grenzflächenforschung, Am Mühlenberg 1, 14476 Potsdam, Germany

${ }^{c}$ Department of Biology and Chemistry, City University of Hong Kong, Tat Chee Avenue, Kowloon, Hong Kong SAR, China

Reprint requests to Prof. Dr. Ulrich Siemeling. Fax: +49 5618044777.

E-mail: siemeling@uni-kassel.de

Z. Naturforsch. 2010, 65b, 1089 - 1096; received March 31, 2010

The surface functionalisation of gold nanoparticles (GNPs) with luminescent platinum complexes has been investigated, utilising $\alpha$-lipoic acid derivatives for GNP stabilisation. Model complexes have been studied to mimic the chemisorption chemistry required to afford GNPs protected by an $\alpha$-lipoic acid-based ligand shell with terminal functionalisation suitable for metal coordination, and the unambiguous binding of the cyclic disulfide moiety at a zero-valent precious metal core through oxidative addition has been confirmed by X-ray crystallography. Subsequently, gold nanoparticles bearing the $\alpha$-lipoic acid-based ligand shell have been prepared and characterised, and a synthetic methodology for the immobilisation of $\mathrm{Pt}^{\mathrm{II}}$ luminophores onto their surface has been established.

Key words: Gold, Luminescence, Nanoparticles, Platinum, Self-assembly

\section{Introduction}

Functionalised monolayer-protected gold nanoparticles are useful for a wide range of applications [1-9]. The surface functionalisation of gold nanoparticles (GNPs) with metal complexes is of particular current interest and represents a burgeoning field in this regard [10-15]. We have developed an interest in gold nanoparticles functionalised with phosphorescent $\mathrm{Pt}^{\mathrm{II}}$ complexes in the ligand shell. While chromophore-functionalised gold nanoparticles which contain organic fluorophores are well known [16, 17], phosphorescent metal-containing analogues are scarce [18 - 20]. $\mathrm{Pt}^{\mathrm{II}}$ complexes (especially those based on tridentate chelate ligands) have been widely investigated as phosphorescent sensors, since the square-planar coordination environment of $\mathrm{Pt}^{\mathrm{II}}$ allows axial interaction with guest molecules, which leads to changes in the local environment of the luminophore and can induce profound photoluminescence responses [21-23].

We have focused our efforts on $\mathrm{Pt}^{\mathrm{II}}$ chelates containing tridentate cyclometallated $\mathrm{C}^{\wedge} \mathrm{N}^{\wedge} \mathrm{N}$ ligands $\left(\mathrm{C}^{\wedge} \mathrm{N}^{\wedge} \mathrm{N}=\right.$ 6-o-arylene-2,2'-bipyridine, Fig. 1), which

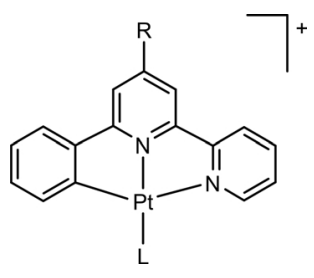

Fig. 1. $\mathrm{Pt}^{\mathrm{II}}$ chelates with tridentate cyclometallated $\mathrm{C}^{\wedge} \mathrm{N}^{\wedge} \mathrm{N}$ ligands relevant to our study. have been utilised as sensors for the recognition and detection of, inter alia, DNA, proteins and volatile organic compounds [24-28]. The luminescence properties of complexes bearing one or more $\mathrm{Pt}^{\mathrm{II}}\left(\mathrm{C}^{\wedge} \mathrm{N}^{\wedge} \mathrm{N}\right)$ luminophores are strongly dependent on weak $\mathrm{Pt} \cdots \mathrm{Pt}$ and $\pi$ - $\pi$ interactions, which can occur intramolecularly or between adjacent molecules in a preorganised environment, and switching between emission from the ${ }^{3}$ MLCT state $\left(\lambda_{\mathrm{em}} c a .550-600 \mathrm{~nm}\right)$ to low-energy emission from the ${ }^{3}$ MMLCT state $\left(\lambda_{\mathrm{em}}>c a .650 \mathrm{~nm}\right)$ can be induced by guest species which perturb these weak interactions $[29,30]$. In the present context the preorganised environment may be provided by the self-assembled ligand shell surrounding a monolayerprotected gold nanoparticle. Phosphorescence quench- 
ing by the gold nanoparticle is expected to be of minor significance, since the energy of the plasmon absorption band $\left(\lambda_{\max } \leq 521 \mathrm{~nm}\right.$ for particles $\left.\leq 22 \mathrm{~nm}\right)$ [31] is considerably higher than that of the low-energy emission band of the chosen $\mathrm{Pt}^{\mathrm{II}}$ luminophores.

\section{Experimental Section}

Synthetic work involving air-sensitive compounds was performed under an atmosphere of dry nitrogen by using standard Schlenk techniques or a conventional glovebox. Solvents (including those for photophysical measurements) were dried and purified according to standard methods. $\left[\mathrm{PtCl}\left(\mathrm{C}^{\wedge} \mathrm{NPh}^{\wedge} \mathrm{N}\right)\right]\left(\mathrm{C}^{\wedge} \mathrm{NPh}^{\wedge} \mathrm{N}=4\right.$-phenyl-6- $o$-phenylene-2,2'-bipyridine) was prepared according to a published procedure [30]. All other chemicals were procured from standard commercial sources and used as received. ${ }^{1} \mathrm{H}$ NMR spectra were recorded on Varian Unity INOVA 500 or Bruker DRX 400 FT-NMR spectrometers (ppm) using $\mathrm{Me}_{4} \mathrm{Si}$ as internal standard, and ${ }^{13} \mathrm{C}$ NMR spectra were recorded on the latter of the two instruments. IR spectra were recorded with Bio-RAD FTS-40A or Perkin-Elmer 1600 series FT-IR spectrophotometers (ATR mode, if not stated otherwise). Highresolution ESI mass spectra were obtained with a micrOTOF instrument (Bruker Daltonics, Bremen, Germany) utilising an Apollo ${ }^{\mathrm{TM}}$ ion funnel ESI ion source. Mass calibration was performed immediately prior to the measurement with ESI Tune Mix Standard (Agilent, Waldbronn, Germany). Standard ESI mass spectra were measured on a Perkin-Elmer Sciex API 365 mass spectrometer. TEM studies were performed with a Zeiss EM $10 \mathrm{C}$ transmission electron microscope at 60 or $80 \mathrm{eV}$, utilising carbon-coated copper grids (Formvar ${ }^{\circledR}$, Plano GmbH, Wetzlar, Germany). TEM data analyses were performed with the programs IMAGEJ and GWYDDION. Elemental analyses were carried out by the microanalytical laboratory of the University of Kassel, or on an Elementar Analysensysteme GmbH Vario EL elemental analyser. UV/Vis absorption spectra were obtained on an Agilent 8453 diode array spectrophotometer. Steady-state emission spectra were recorded on a SPEX FluoroLog 3-TCSPC spectrophotometer equipped with a Hamamatsu R928 PMT detector. Sample solutions were degassed with at least three freeze-pump-thaw cycles. X-Ray crystal structure analyses: For each data collection a single crystal was mounted on a glass fibre, and all geometric and intensity data were taken from this sample. Data collection using $\mathrm{Mo} K_{\alpha}$ radiation ( $\lambda=0.71073 \AA$ ) was made on a Stoe IPDS2 diffractometer equipped with a 2-circle goniometer and an area detector. Absorption correction was done by integration using X-RED [32]. The data sets were corrected for Lorentz and polarisation effects. The structures were solved by $\mathrm{Di}$ rect Methods (SHELXS-97) and refined using alternating cycles of least-squares refinements against $F^{2}$ (SHELXL-97)
Table 1. Crystal data and structure refinement for compounds 1 and $2 \cdot 3.5 \mathrm{C}_{6} \mathrm{H}_{6}$.

\begin{tabular}{|c|c|c|}
\hline Compound & 1 & $\mathbf{2} \cdot 3.5 \mathrm{C}_{6} \mathrm{H}_{6}$ \\
\hline Empirical formula & $\mathrm{C}_{13} \mathrm{H}_{18} \mathrm{~N}_{2} \mathrm{OS}_{2}$ & $\mathrm{C}_{70} \mathrm{H}_{69} \mathrm{~N}_{2} \mathrm{OP}_{2} \mathrm{PtS}_{2}$ \\
\hline Formula weight & 282.41 & 1275.42 \\
\hline Temperature, $\mathrm{K}$ & $153(2)$ & $143(2)$ \\
\hline Crystal system & monoclinic & triclinic \\
\hline Space group & $P 2_{1} / c$ & $P \overline{1}$ \\
\hline$a, \AA$ & $8.8635(14)$ & $10.2582(13)$ \\
\hline$b, \AA$ & $13.9845(16)$ & $14.003(3)$ \\
\hline$c, \AA$ & $11.6558(14)$ & 23.073(3) \\
\hline$\alpha, \operatorname{deg}$ & 90 & $80.960(13)$ \\
\hline$\beta, \operatorname{deg}$ & $90.737(11)$ & $79.510(11)$ \\
\hline$\gamma, \operatorname{deg}$ & 90 & $71.567(12)$ \\
\hline Cell volume, $\AA^{3}$ & $1444.6(3)$ & $3074.2(8)$ \\
\hline$Z$ & 4 & 2 \\
\hline$d_{\text {calc. }}, \mathrm{g} \mathrm{cm}^{-3}$ & 1.30 & 1.38 \\
\hline$\mu, \mathrm{mm}^{-1}$ & 0.4 & 2.4 \\
\hline$F(000)$ & 600 & 1302 \\
\hline$\theta$ range, deg & 2.30 to 24.99 & 1.45 to 25.23 \\
\hline \multirow[t]{3}{*}{ Index ranges } & $-10 \leq h \leq 10$ & $-12 \leq h \leq 12$ \\
\hline & $-12 \leq k \leq 16$ & $-16 \leq k \leq 16$ \\
\hline & $-13 \leq l \leq 12$ & $-27 \leq l \leq 26$ \\
\hline Refls. collect. / indep. & $5191 / 2438 /$ & $20133 / 10308 /$ \\
\hline$R_{\text {int }}$ & 0.0988 & 0.1759 \\
\hline Refls. observed & 1157 & 2965 \\
\hline$T_{\min } / T_{\max }$ & $0.9201 / 0.9955$ & $0.5622 / 0.8253$ \\
\hline Data / restraints / params & $2438 / 0 / 166$ & $10308 / 0 / 262$ \\
\hline \multirow{2}{*}{$\begin{array}{l}\text { Final indices } R 1 / \\
\quad w R 2[I \geq 2 \sigma(I)]\end{array}$} & $0.0700 /$ & $0.0825 /$ \\
\hline & 0.1742 & 0.1540 \\
\hline \multirow{2}{*}{$\begin{array}{l}\text { Final indices } R 1 / \text { } \\
\quad w R 2 \text { (all data) }\end{array}$} & $0.1355 /$ & $0.2227 /$ \\
\hline & 0.1999 & 0.1954 \\
\hline GOF on $F^{2}$ & 0.905 & 0.722 \\
\hline \multirow{2}{*}{$\begin{array}{l}\text { Largest diff. peak / } \\
\text { hole, e } \AA^{-3}\end{array}$} & 0.514 & 1.811 \\
\hline & -0.326 & -1.730 \\
\hline
\end{tabular}

[33]. All non-H atoms were found in difference Fourier maps and were refined with anisotropic displacement parameters. $\mathrm{H}$ atoms were placed in constrained positions according to the riding model with the 1.2-fold isotropic displacement parameters. The solvent molecules present in $\mathbf{2} \cdot 3.5 \mathrm{C}_{6} \mathrm{H}_{6}$ have been included in the model with constrained hexagonal symmetry. Pertinent crystallographic data are collected in Table 1. Graphical representations were made using ORTEP-3 WIN [34].

CCDC 746851-746852 contain the supplementary crystallographic data for this paper. These data can be obtained free of charge from The Cambridge Crystallographic Data Centre via www.ccdc.cam.ac.uk/data_request/cif.

\section{Preparation of lip-C(O)NH-py (1)}

HOBt (656 mg, $4.85 \mathrm{mmol})$ was added to a stirred solution of $\alpha$-lipoic acid (1.00 g, $4.85 \mathrm{mmol})$, 4-aminopyridine (456 mg, $4.85 \mathrm{mmol})$ and $\mathrm{EDCCl}(296 \mathrm{mg}, 5.34 \mathrm{mmol})$ in dichloromethane $(50 \mathrm{~mL})$. After $65 \mathrm{~h}$ the mixture was washed with water $(4 \times 50 \mathrm{~mL})$ and dried with $\mathrm{CaSO}_{4}$. Volatile components were removed in vacuo, affording the 
crude product as a light-yellow solid which was dissolved in a minimum amount of ethyl acetate and purified by column chromatography (silica gel, ethyl acetate- $n$-hexane $4: 1$ ). Yield $548 \mathrm{mg}(40 \%) .-{ }^{1} \mathrm{H} \mathrm{NMR}\left(\mathrm{CDCl}_{3}\right): \delta=1.49(\mathrm{~m}, 2 \mathrm{H})$, $1.70(\mathrm{~m}, 4 \mathrm{H}), 1.89(\mathrm{~m}, 1 \mathrm{H}), 2.37(\mathrm{~m}, 3 \mathrm{H}), 3.10(\mathrm{~m}, 1 \mathrm{H})$, $3.16(\mathrm{~m}, 1 \mathrm{H}), 3.56(\mathrm{~m}, 1 \mathrm{H}), 7.51(\mathrm{~m}, 2 \mathrm{H}), 7.79(\mathrm{~s}, 1 \mathrm{H}), 8.46$ $(\mathrm{m}, 2 \mathrm{H}) .-\mathrm{IR}: v(\mathrm{C}=\mathrm{O}) 1697, v\left(\mathrm{C}-\mathrm{C}_{\text {arom }}\right) 1590, v(\mathrm{C}-\mathrm{N})+$ $\delta(\mathrm{N}-\mathrm{H}) 1521 \mathrm{~cm}^{-1}$. - HRMS ((+)-ESI): $\mathrm{m} / z=283.09333$ (calcd. 283.09388 for $\mathrm{C}_{13} \mathrm{H}_{19} \mathrm{~N}_{2} \mathrm{OS}_{2},[\mathrm{M}+\mathrm{H}]^{+}$). - Anal. for $\mathrm{C}_{13} \mathrm{H}_{18} \mathrm{~N}_{2} \mathrm{OS}_{2}$ (282.4): calcd. C 55.29, H 6.42, N 9.92; found C 55.44, H 6.22, N 9.90.

\section{Preparation of the $P t^{I I}$ chelate 2}

A $5 \mathrm{~mm}$ NMR tube was charged with $\left[\mathrm{Pt}\left(\mathrm{PPh}_{3}\right)_{4}\right](50 \mathrm{mg}$, $0.04 \mathrm{mmol})$ and $1(11 \mathrm{mg}, 0.04 \mathrm{mmol})$, and $\mathrm{C}_{6} \mathrm{D}_{6}(2 \mathrm{~mL})$ was added. The solution was investigated by ${ }^{31} \mathrm{P}$ NMR spectroscopy, which indicated that the reaction was essentially complete after $c a .6 \mathrm{~h}$; yield (NMR) quantitative. After $12 \mathrm{~h}$ the solution was carefully layered with $n$-hexane to induce crystallisation. Light-orange single crystals suitable for an $\mathrm{X}$-ray diffraction study were obtained after several days. ${ }^{1} \mathrm{H}$ $\operatorname{NMR}\left(\mathrm{C}_{6} \mathrm{D}_{6}\right): \delta=1.15(\mathrm{~m}, 1 \mathrm{H}), 1.27(\mathrm{~m}, 2 \mathrm{H}), 1.49(\mathrm{~m}$, $2 \mathrm{H}), 1.60(\mathrm{~m}, 1 \mathrm{H}), 1.95(\mathrm{~m}, 1 \mathrm{H}), 2.23(\mathrm{~m}, 2 \mathrm{H}), 3.10(\mathrm{~m}$, $1 \mathrm{H}), 3.19(\mathrm{~m}, 1 \mathrm{H}), 7.25(\mathrm{~m} 36 \mathrm{H}), 7.55(\mathrm{~m}, 2 \mathrm{H}), 7.60(\mathrm{~s}$, $1 \mathrm{H}), 8.4(\mathrm{~m}, 2 \mathrm{H}) .-{ }^{31} \mathrm{P}$ NMR $\left(\mathrm{C}_{6} \mathrm{D}_{6}\right): \delta=23.7\left(\mathrm{~d}, J_{\mathrm{pp}}=\right.$ $20.5 \mathrm{~Hz}), 26.2\left(\mathrm{~d}, J_{\mathrm{pp}}=20.5 \mathrm{~Hz}\right)$.

\section{Preparation of lip-C(O)NH-Ph(3)}

Aniline (452 mg, $4.85 \mathrm{mmol}$ ) was added to a solution of $\alpha$-lipoic acid (1.00 g, $4.85 \mathrm{mmol})$, DCC (1.00 g, $4.85 \mathrm{mmol})$ and $\mathrm{HOBt}(655 \mathrm{mg}, 4.85 \mathrm{mmol})$ in dichloromethane $(30 \mathrm{~mL})$. After $72 \mathrm{~h}$ the precipitate was filtered off. The filtrate was reduced to dryness in vacuo, affording the crude product as a light-yellow solid, which was purified by column chromatography (silica gel, dichloromethane-methanol 30:1). Yield $519 \mathrm{mg}(38 \%) .-{ }^{1} \mathrm{H} \mathrm{NMR}\left(\mathrm{CDCl}_{3}\right): \delta=1.51(\mathrm{~m}, 2 \mathrm{H}), 1.73$ $(\mathrm{m}, 4 \mathrm{H}), 1.90(\mathrm{~m}, 1 \mathrm{H}), 2.36(\mathrm{~m}, 2 \mathrm{H}), 2.45(\mathrm{~m}, 1 \mathrm{H}), 3.10$ $(\mathrm{m}, 1 \mathrm{H}), 3.17(\mathrm{~m}, 1 \mathrm{H}), 3.57(\mathrm{~m}, 1 \mathrm{H}), 7.09(\mathrm{~m}, 1 \mathrm{H}), 7.19(\mathrm{~s}$, $1 \mathrm{H}$ ), 7.30 ("d", apparent $J=7.9 \mathrm{~Hz}, 2 \mathrm{H}$ ), 7.49 (“d”, apparent $J=8.0 \mathrm{~Hz}, 2 \mathrm{H})$. - IR: $v=1655,1597,1533 \mathrm{~cm}^{-1}$. HRMS ((+)-ESI): $m / z=282.09880$ (cald. 282.09863 for $\left.\mathrm{C}_{14} \mathrm{H}_{20} \mathrm{NOS}_{2},[\mathrm{M}+\mathrm{H}]^{+}\right)$. - Anal. for $\mathrm{C}_{14} \mathrm{H}_{19} \mathrm{NOS}_{2}$ (281.4): calcd. C 59.75, H 6.80, N 4.98; found C 60.19, H 7.42, N 4.98 .

\section{Preparation of $\left[P t(1)\left(C^{\wedge} N P h^{\wedge} N\right)\right] P F_{6}(4)$}

A suspension of $\left[\mathrm{PtCl}\left(\mathrm{C}^{\wedge} \mathrm{NPh}^{\wedge} \mathrm{N}\right)\right](31 \mathrm{mg}, 0.058 \mathrm{mmol})$ and $1(19 \mathrm{mg}, 0.067 \mathrm{mmol})$ in $\mathrm{CH}_{3} \mathrm{CN} / \mathrm{CH}_{3} \mathrm{OH}(1: 1,12 \mathrm{~mL})$ was refluxed for $48 \mathrm{~h}$ to give a clear orange solution. The solution was filtered into methanolic $\left[\mathrm{NH}_{4}\right]\left[\mathrm{PF}_{6}\right](47 \mathrm{mg}$, $0.29 \mathrm{mmol}$ ), which gave a yellow precipitate upon cooling.
The precipitate was collected and washed with diethyl ether. Recrystallisation by diffusion of diethyl ether into a $\mathrm{CH}_{3} \mathrm{CN}$ solution afforded a yellow crystalline solid. Yield $34 \mathrm{mg}$ $(75 \%) .-{ }^{1} \mathrm{H}$ NMR $\left(\mathrm{CD}_{3} \mathrm{CN}\right): \delta=1.48-1.55(\mathrm{~m}, 2 \mathrm{H})$, $1.63-1.79(\mathrm{~m}, 4 \mathrm{H}), 1.91-1.97(\mathrm{~m}, 1 \mathrm{H}), 2.48(\mathrm{~m}, 3 \mathrm{H})$, $3.11-3.23(\mathrm{~m}, 2 \mathrm{H}), 3.61-3.68(\mathrm{~m}, 1 \mathrm{H}), 6.43(\mathrm{~m}, 1 \mathrm{H}), 7.08$ $(\mathrm{m}, 2 \mathrm{H}), 7.59(\mathrm{~m}, 4 \mathrm{H}), 7.66(\mathrm{~m}, 1 \mathrm{H}), 7.80(\mathrm{~d}, J=7.0 \mathrm{~Hz}$, $2 \mathrm{H}), 7.86(\mathrm{~m}, 2 \mathrm{H}), 7.94(\mathrm{~s}, 1 \mathrm{H}), 8.03(\mathrm{~d}, J=4.7 \mathrm{~Hz}, 1 \mathrm{H})$, $8.06(\mathrm{~s}, 1 \mathrm{H}), 8.21(\mathrm{~m}, 1 \mathrm{H}), 8.29(\mathrm{~d}, J=8.0 \mathrm{~Hz}, 1 \mathrm{H}), 8.63(\mathrm{~d}$, $J=7.0 \mathrm{~Hz}, 2 \mathrm{H}), 9.14(\mathrm{~s}, 1 \mathrm{H}) .-{ }^{13} \mathrm{C} \mathrm{NMR}\left(\mathrm{CD}_{3} \mathrm{CN}\right): \delta=$ 25.4, 25.6, 29.4, 35.4, 37.7, 39.3, 41.1, 57.4, 116.7, 125.3, 126.2, 126.6, 128.6, 129.4, 130.3, 131.8, 132.0, 133.3, 133.5, 137.3, 141.9, 142.0, 148.3, 149.0, 150.1, 154.1, 154.4, 156.1, 157.8, 166.9, 174.3. - IR (KBr): $v(\mathrm{C}=\mathrm{O}) 1708, v\left(\mathrm{C}-\mathrm{C}_{\text {arom }}\right)$ 1613, $v(\mathrm{C}-\mathrm{N})+\delta(\mathrm{N}-\mathrm{H}) 1507 \mathrm{~cm}^{-1}$. - UV/Vis $\left(\mathrm{CH}_{3} \mathrm{CN}\right)$ : $\lambda_{\max }\left(\varepsilon\right.$ in $\left.\mathrm{L} \mathrm{mol}^{-1} \mathrm{~cm}^{-1}\right)=329$ (9940), 360 (5880), 426 (2190) $\mathrm{nm}$. - Emission $\left(\mathrm{CH}_{3} \mathrm{CN}\right): \lambda_{\max }=556 \mathrm{~nm}\left(\lambda_{\mathrm{ex}}=\right.$ $425 \mathrm{~nm}$ ). - MS ((+)-ESI): $m / z=784.4$ (calcd. 784.2 for $\mathrm{C}_{35} \mathrm{H}_{33} \mathrm{~N}_{4} \mathrm{OPtS}_{2},[\mathrm{M}]^{+}$). - Anal. for $\mathrm{C}_{35} \mathrm{H}_{33} \mathrm{~N}_{4} \mathrm{~F}_{6} \mathrm{OPPtS}_{2}$ (929.8): calcd. C 45.21, H 3.58, N 6.03; found C 45.44, H 3.68, N 5.89.

\section{Preparation of 3@GNP}

$\mathrm{H}\left[\mathrm{AuCl}_{4}\right] \cdot 3 \mathrm{H}_{2} \mathrm{O} \quad(200 \mathrm{mg}, \quad 0.51 \mathrm{mmol})$ and $[(n-$ $\left.\left.\mathrm{C}_{8} \mathrm{H}_{17}\right)_{4} \mathrm{~N}\right] \mathrm{Br}(750 \mathrm{mg}, 1.4 \mathrm{mmol})$ were dissolved in a mixture of water $(25 \mathrm{~mL})$ and toluene $(40 \mathrm{~mL})$. The mixture was stirred vigorously for $10 \mathrm{~min}$, and $\mathbf{3}(282 \mathrm{mg}$, $1.00 \mathrm{mmol}$ ) was added. Stirring was continued for a further $10 \mathrm{~min}$ and the mixture cooled to $0{ }^{\circ} \mathrm{C}$ during this time. A freshly prepared ice-cold solution of $\mathrm{Na}\left[\mathrm{BH}_{4}\right]$ (190 mg, $5.00 \mathrm{mmol})$ in water $(12.5 \mathrm{~mL})$ was added dropwise to the stirred mixture over the course of $15 \mathrm{~min}$. The stirred mixture was kept at $0{ }^{\circ} \mathrm{C}$ for another $30 \mathrm{~min}$ and was subsequently allowed to warm up to r.t. After $20 \mathrm{~h}$ the dark-violet organic layer was separated, and volatile components were removed in vacuo. The residue was dissolved in dichloromethane $(20 \mathrm{~mL})$. The product was precipitated by dropwise addition of $n$-hexane $(50 \mathrm{~mL})$ and collected by decanting. The precipitation procedure was repeated twice and the product finally isolated by filtration, which afforded a very dark, viscous paste. Yield $160 \mathrm{mg}$. - Particle size (TEM) $(2.74 \pm 0.78)$ nm. $-{ }^{1} \mathrm{H} \mathrm{NMR}\left(\mathrm{CDCl}_{3}\right): \delta=1.50(\mathrm{~m}, 2 \mathrm{H}), 1.71(\mathrm{~m}, 4 \mathrm{H})$, $1.90(\mathrm{~m}, 1 \mathrm{H}), 2.41(\mathrm{~m}, 3 \mathrm{H}), 3.09(\mathrm{~m}, 1 \mathrm{H}), 3.14(\mathrm{~m}, 1 \mathrm{H})$, $3.55(\mathrm{~m}, 1 \mathrm{H}), 7.03(\mathrm{~m}, 1 \mathrm{H}), 7.17(\mathrm{~m}, 2 \mathrm{H}), 7.25(\mathrm{~m}, 2 \mathrm{H})$, 7.60 (m, 2 H). - IR: $v=1675,1599,1545 \mathrm{~cm}^{-1}$.

\section{Preparation of 4@GNP}

$\mathrm{H}\left[\mathrm{AuCl}_{4}\right] \cdot 3 \mathrm{H}_{2} \mathrm{O}(0.46 \mathrm{mg}, 1.18 \mu \mathrm{mol}), 4(0.96 \mathrm{mg}$, $1.18 \mu \mathrm{mol})$ and $n$-octane thiol $(0.17 \mathrm{mg}, 1.18 \mu \mathrm{mol})$ were dissolved in $\mathrm{CH}_{3} \mathrm{CN}(3 \mathrm{~mL})$, and an aqueous solution of $\mathrm{Na}\left[\mathrm{BH}_{4}\right](153 \mu \mathrm{L}, 58 \mathrm{~mm}, 7.5$ equiv.) was slowly added with constant stirring, which caused the solution to darken. 


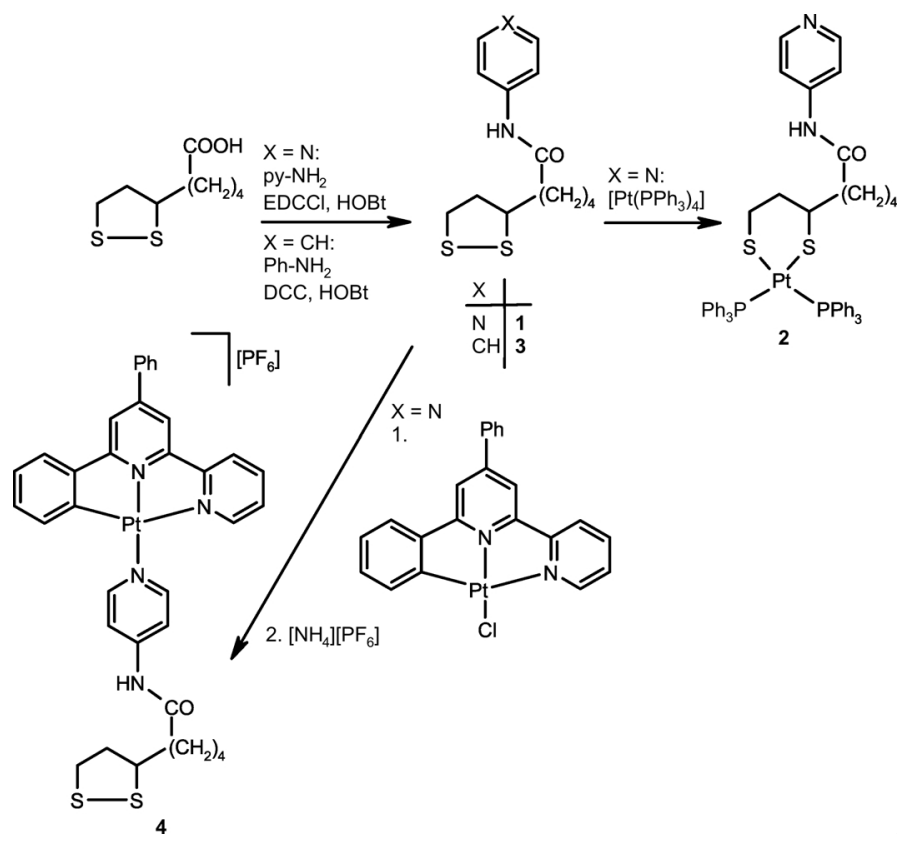

Scheme 1. New compounds prepared in this investigation.

After $5 \mathrm{~min}$, this resulted in the slow formation of a black precipitate, which was collected after $30 \mathrm{~min}$ by centrifuge, washed copiously with $\mathrm{CH}_{3} \mathrm{CN}$ and dried in vacuo. Yield $0.28 \mathrm{mg}$. - Particle size (TEM) $(2.38 \pm 0.67) \mathrm{nm}$. - Emission: $\lambda_{\max }\left(\mathrm{CH}_{2} \mathrm{Cl}_{2}, 298 \mathrm{~K}\right)=546\left(\lambda_{\mathrm{ex}}=300\right) \mathrm{nm}$. $-\mathrm{IR}$ $(\mathrm{KBr}): v(\mathrm{C}=\mathrm{O}) \sim 1700(\mathrm{vw}), v\left(\mathrm{C}-\mathrm{C}_{\text {arom }}\right) 1605, v(\mathrm{C}-\mathrm{N})+$ $\delta(\mathrm{N}-\mathrm{H}) 1477 \mathrm{~cm}^{-1}$. - UV/Vis (aqueous acetonitrile): $\lambda_{\max }=$ 240, 279, 328, 360, 426, 540 (br.) nm.

\section{Results and Discussion}

Our strategy involves the attachment of luminescent $\mathrm{Pt}^{\mathrm{II}} \mathrm{C}^{\wedge} \mathrm{N}^{\wedge} \mathrm{N}$ chelates to gold nanoparticles. This can be achieved by a linker which contains terminal units suitable for (1) chemisorption on gold, and (2) binding suitable $\mathrm{Pt}^{\mathrm{II}}$ luminophore fragments. Owing to our experience with $\alpha$-lipoic acid (lip- $\mathrm{COOH}$ ) derivatives for the fabrication of SAMs on gold [35,36], we decided to utilise lip-C(O)NH-py (1) (py = pyrid-4yl) as the linker component. The 1,2-dithiolane unit is excellently suited for chemisorption on gold, while the terminal pyridyl unit is known to readily coordinate $\left[\mathrm{Pt}^{\mathrm{II}}\left(\mathrm{C}^{\wedge} \mathrm{N}^{\wedge} \mathrm{N}\right)\right]^{+}$moieties $[37,38]$. The synthesis of $\mathbf{1}$ was easily accomplished by the condensation of lip- $\mathrm{COOH}$ with $\mathrm{pyNH}_{2}$ using the established peptide coupling reagent combination of $\mathrm{N}$-ethyl$N^{\prime}$-(3-dimethylaminopropyl)carbodiimide hydrochloride $(\mathrm{EDCCl})$ and 1-hydroxybenzotriazol $(\mathrm{HOBt})$ in dichloromethane solvent (Scheme 1) [39-41].



Fig. 2. Molecular structure and aggregation of $\mathbf{1}$ in the crystal.

The compound was structurally characterised by a single-crystal X-ray diffraction study (Fig. 2). Bond lengths and angles are unexceptional. While no amide $\mathrm{C}=\mathrm{O} \cdots \mathrm{H}-\mathrm{N}$ hydrogen bonds occur, $\mathrm{N}-\mathrm{H} \cdots$ py hydrogen bonds are observed between neighbouring molecules in the crystal, with parameters $(\mathrm{N} \cdots \mathrm{N}$ ca. $2.90 \AA, \mathrm{N}-\mathrm{H}-\mathrm{N}$ ca. $\left.165^{\circ}\right)$ in accord with a moderate bond strength [42]. Similar intermolecu- 
lar $\mathrm{N}-\mathrm{H} \cdots$ py interactions have been observed previously [43].

The chemisorption of $\mathbf{1}$ on the surface of a gold nanoparticle is expected to occur by an oxidative addition of the 1,2-dithiolane unit to afford two thiolategold bonds [44], but a competing adsorption of the pyridyl moiety cannot be ruled out [45-47]. We have therefore reacted 1 with the zero-valent $\mathrm{Pt}$ complex $\left[\mathrm{Pt}\left(\mathrm{PPh}_{3}\right)_{4}\right]$ and found that an oxidative addition proceeded smoothly and swiftly at r.t., affording the $\mathrm{Pt}^{\mathrm{II}}$ chelate 2 in good yield (Scheme 1). This lends further credence to the notion that $\mathbf{1}$ chemisorbs on gold by an oxidative addition of the S-S bond. The $\mathrm{Pt}^{\mathrm{II}}$ chelate was structurally characterised by single-crystal X-ray diffraction (Fig. 3). Bond parameters compare well to those of closely related compounds [35,48]. The Pt atom resides in a distorted square-planar coordination environment: the P-Pt-P and S-Pt-S angles are $97.6(2)$ and $93.2(2)^{\circ}$, respectively, while the two cis-P-Pt-S bond angles are $87.9(2)$ and $81.8(2)^{\circ}$, and the sum of angles around $\mathrm{Pt}$ is $360.5^{\circ}$. The Pt-P bond lengths [2.336(5) and 2.278(6) $\AA$ ] and the Pt-S bond lengths $[2.325(5)$ and 2.343(6) $\AA$ ] differ only slightly. The molecules are aggregated as antiparallel dimers in the crystal, held together by intermolecular N-H..S interactions (N...S $3.39 \AA, \mathrm{H} \cdots \mathrm{S} 2.53 \AA$, N-H-S $166.1^{\circ}$ ) that correspond to hydrogen bonds of medium strength [49].

The assembly of three components is required in order to obtain gold nanoparticles functionalised with phosphorescent $\mathrm{Pt}$ complexes in the ligand shell, viz. the nanoparticle, the linker and a suitable Pt complex moiety. First of all, we have investigated the possibility to chemisorb the linker $\mathbf{1}$ on gold nanoparticles, in order to introduce the $\mathrm{Pt}^{\mathrm{II}}$ component in the following step by chemical postmodification of the linkercontaining nanoparticles. Two principal procedures are possible for the synthesis of such linker-containing gold nanoparticles, viz. by ligand substitution of preformed monolayer-protected nanoparticles or by direct synthesis. The direct synthesis involves the reduction of $\mathrm{H}\left[\mathrm{AuCl}_{4}\right]$ with $\mathrm{Na}\left[\mathrm{BH}_{4}\right]$ in the presence of an excess of 1. We have followed the two-phase method (water/toluene solvent system, phase transfer catalyst) established by Brust et al. [50], using a protocol developed by Murray and coworkers [51]. Despite numerous attempts under various conditions of temperature, concentration and ratio of components, this approach did not afford soluble nanoparticles. Instead,

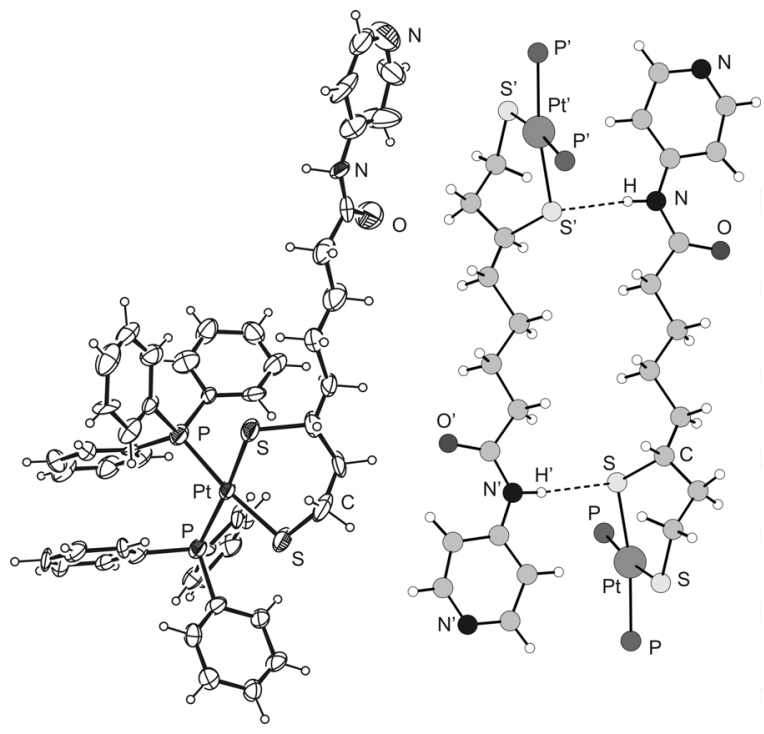

Fig. 3. Molecular structure (left) and aggregation of 2 (right, $\mathrm{Ph}$ groups are omitted for clarity) in the crystal.

an intractable black material was obtained which was completely insoluble in any solvent. When the reaction was performed in acetonitrile instead of a biphasic solvent system, similar results were obtained. The alternative ligand substitution approach was equally futile. We utilised triphenylphosphane-stabilised gold nanoparticles $\left(\mathrm{Ph}_{3} \mathrm{P} @ \mathrm{GNPs}\right)$ obtained by the reduction of $\left[\mathrm{AuCl}\left(\mathrm{PPh}_{3}\right)\right]$ with $\mathrm{B}_{2} \mathrm{H}_{6}$ in toluene according to the protocol developed by Schmid [52], which in our hands afforded particles with a diameter of $(1.77 \pm 0.5)$ $\mathrm{nm}$ according to TEM analysis. A dichloromethane solution of these nanoparticles did not show the plasmon absorption band typical for larger (>ca. $2 \mathrm{~nm}$ ) gold nanoparticles, which is located at $c a .520 \mathrm{~nm}$ [5]. Treatment of this solution with $\mathbf{1}$ at r.t. led to pronounced changes in the UV/Vis spectrum. A very broad band at ca. $670 \mathrm{~nm}$ was observed, typical for large aggregated or agglomerated particles [53], as subsequently corroborated by TEM analysis.

These results prompted us to study the role of $\mathbf{1}$ in more detail by performing similar experiments with its phenyl analogue lip-C(O)NH-Ph (3), which was synthesised by the condensation of lip- $\mathrm{COOH}$ with $\mathrm{PhNH}_{2}$ using $N, N^{\prime}$-dicyclohexylcarbodiimide (DCC) as coupling reagent (Scheme 1). By simple direct synthesis (Brust/Murray conditions) we were able to obtain soluble functionalised gold nanoparticles which were not prone to form larger aggregates. The presence of a weak surface plasmon band at $518 \mathrm{~nm}$ in 

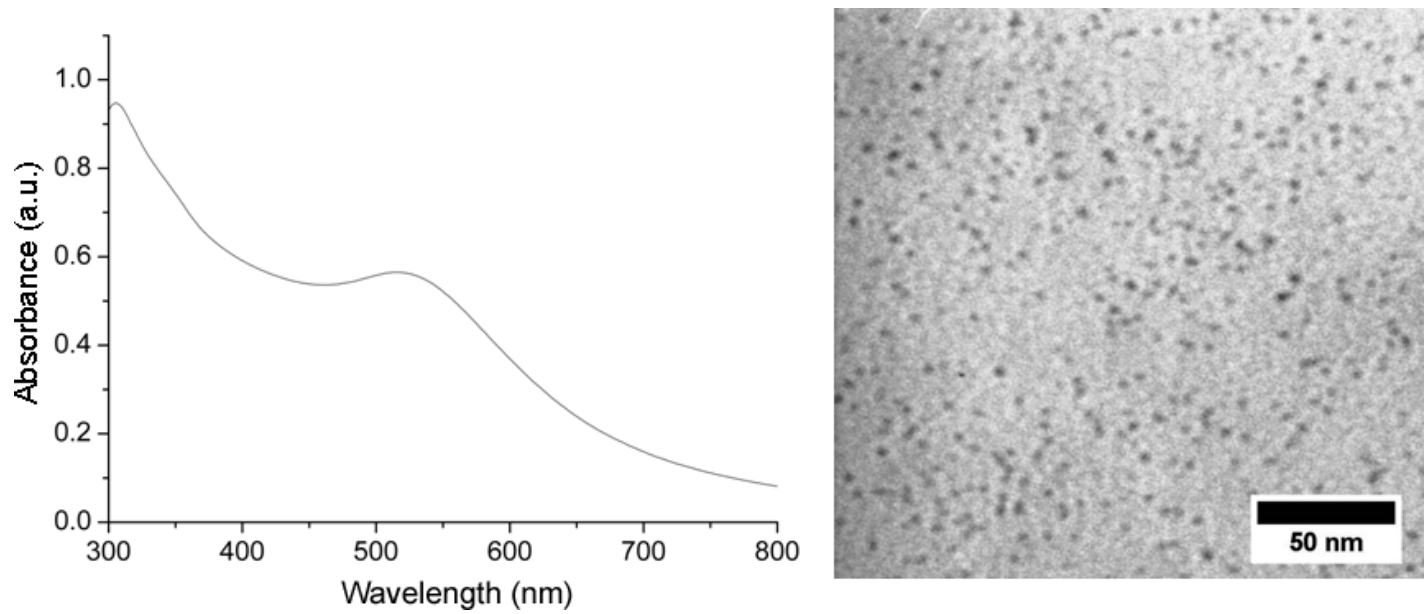

Fig. 4. UV/Vis spectrum (left; in toluene/ $\mathrm{H}_{2} \mathrm{O}$ ) and TEM image (right) for gold nanoparticles functionalised with lip-C(O)NHPh (3) (3@GNP).

the UV/Vis spectrum indicated an average nanoparticle diameter between 2 and $3 \mathrm{~nm}$, which is reassuringly compatible with the value of $(2.74 \pm 0.78)$ nm obtained from the TEM investigation (Fig. 4). The presence of substantial amounts of $\mathbf{3}$ chemisorbed on the nanoparticles was clearly evident from IR and ${ }^{1} \mathrm{H}$ NMR spectra. The fact that the use of the pyridyl-substituted $\alpha$ lipoic acid derivative $\mathbf{1}$ did not allow the synthesis of soluble gold nanoparticles, but rather induced aggregation and agglomeration, can thus be attributed to the presence of the pyridyl group. This group may become engaged in substantial intermolecular hydrogen bonding, as is evident already from the crystal structure of 1 (vide supra). Intermolecular hydrogen bonds within or between monolayers may also constitute the main reason for our failure to prepare soluble gold nanoparticles with a ligand shell based on $\mathbf{1}$.

The intended approach to chemisorb the linker 1 on gold nanoparticles in order to introduce the $\mathrm{Pt}^{\mathrm{II}}$ component in the following step by chemical postmodification of linker-containing nanoparticles was evidently unsuccessful. We therefore turned our attention to the second approach based on the attachment of the $\mathrm{Pt}^{\mathrm{II}}$ moiety to the linker $\mathbf{1}$ to afford an adsorbate species of the type $\left[\operatorname{Pt}(\mathbf{1})\left(\mathrm{C}^{\wedge} \mathrm{N}^{\wedge} \mathrm{N}\right)\right]^{+}$, which could be employed for chemisorption on a gold nanoparticle in the subsequent step. The reaction of $\mathbf{1}$ with the $\mathrm{Pt}^{\mathrm{II}}$ complex $\left[\mathrm{PtCl}\left(\mathrm{C}^{\wedge} \mathrm{NPh}^{\wedge} \mathrm{N}\right)\right]$ was performed in a mixture of methanol and acetonitrile at reflux temperature, followed by anion metathesis, to give the target product $\left[\operatorname{Pt}(\mathbf{1})\left(\mathrm{C}^{\wedge} \mathrm{NPh}^{\wedge} \mathrm{N}\right)\right] \mathrm{PF}_{6}(\mathbf{4}$, Scheme 1$)$, which was char-



Fig. 5. TEM image for the product obtained from the reduction of $\mathrm{H}\left[\mathrm{AuCl}_{4}\right]$ with $\mathrm{Na}\left[\mathrm{BH}_{4}\right]$ in the presence of $\mathbf{4}$ and $n$ octane thiol.

acterised by ${ }^{1} \mathrm{H}$ and ${ }^{13} \mathrm{C}$ NMR spectroscopy, IR spectroscopy and ESI-MS.

The direct one-pot synthesis (reduction of $\mathrm{H}\left[\mathrm{AuCl}_{4}\right]$ with $\mathrm{Na}\left[\mathrm{BH}_{4}\right]$ in the presence of 4 ) was performed in the presence of $n$-octane thiol to facilitate stabilisation of nanoparticles. A monophasic polar medium (aqueous acetonitrile) was chosen instead of the traditional biphasic water/toluene medium, because the ionic adsorbate species $\mathbf{4}$ exhibits reasonable solubility in polar organic solvents only. Due to the monophasic nature of the reaction, no transfer catalyst was required. The average diameter of the resulting nanoparticles turned out to be $(2.38 \pm 0.67) \mathrm{nm}$ according to TEM analysis 

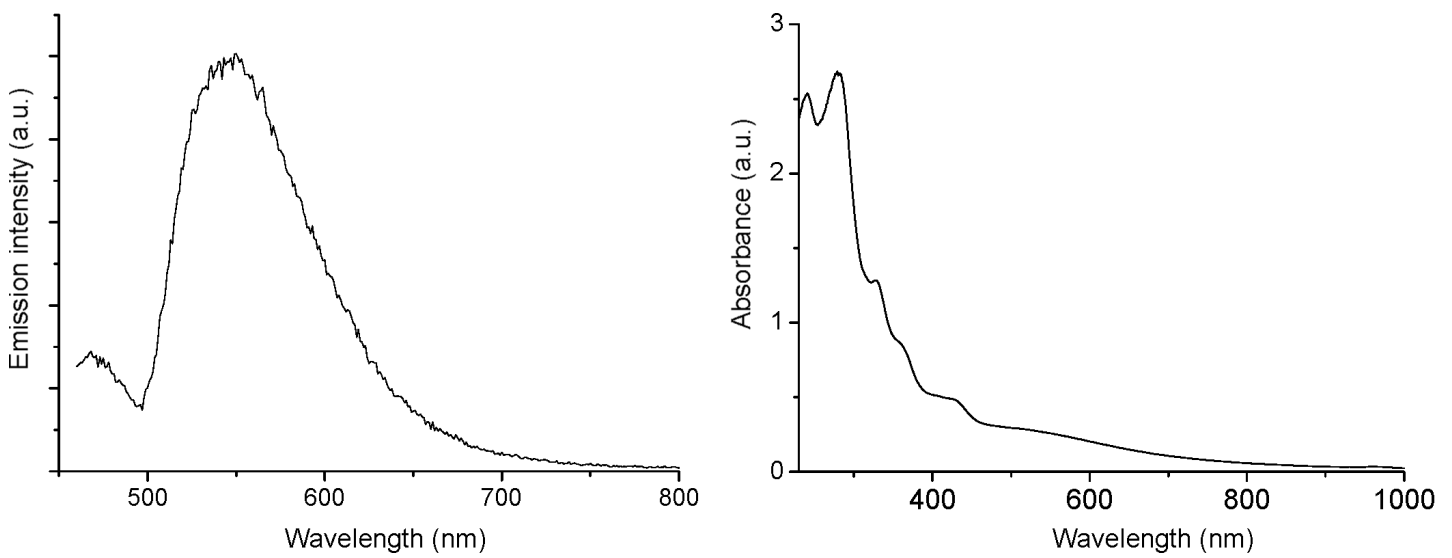

Fig. 6. Emission spectrum (left; in $\mathrm{CH}_{2} \mathrm{Cl}_{2}$ at $298 \mathrm{~K}, \lambda_{\mathrm{ex}}=300 \mathrm{~nm}$ ) and UV/Vis spectrum (right; in aqueous acetonitrile) of the product obtained from the reduction of $\mathrm{H}\left[\mathrm{AuCl}_{4}\right]$ with $\mathrm{Na}\left[\mathrm{BH}_{4}\right]$ in the presence of 4 and $n$-octane thiol.

(Fig. 5), which is similar to the value of $(2.74 \pm 0.78)$ nm determined for $3 @$ GNP.

IR spectroscopic data are in accord with the presence of 4 chemisorbed on the nanoparticle surface. A $v\left(\mathrm{C}-\mathrm{C}_{\text {arom }}\right)$ band is located at $1605 \mathrm{~cm}^{-1}$, which is close to the corresponding value of $1613 \mathrm{~cm}^{-1}$ observed for 4 . The $v(\mathrm{C}-\mathrm{N})$ and $\delta(\mathrm{N}-\mathrm{H})$ bands observed at $1507 \mathrm{~cm}^{-1}$ in the case of $\mathbf{4}$ have experienced a chemisorption-induced red shift of $c a .30 \mathrm{~cm}^{-1}$ and appear at the low end of the amide I region [54]. Not unexpectedly, the fairly weak intensity of the $v(\mathrm{C}=\mathrm{O})$ band at $1700 \mathrm{~cm}^{-1}$ indicates an approximately orthogonal orientation of this moiety with respect to the surface normal according to the surface selection rule $[55,56]$. The UV/Vis and emission spectra, too, are compatible with the presence of luminescent Ptfunctionalised nanoparticles (Fig. 6). Future work will address the photophysical response of these nanoparticles towards suitable analytes which are prone to axial interaction with the square-planar $\mathrm{Pt}^{\mathrm{II}}$ coordination environment.

\section{Acknowledgements}

The work described in this paper was supported by a travel grant from the Germany/Hong Kong Joint Research Scheme sponsored by the Research Grants Council of Hong Kong (Reference No. G_HK004/06) and the German Academic Exchange Service (DAAD, D/06 00385), and by a grant from City University of Hong Kong (7002130; for research activities performed in Hong Kong). We are grateful to Umicore AG \& Co. KG (Hanau, Germany) for a generous gift of precious metal compounds. Prof. H. Zöltzer (Institute of Biology, University of Kassel) is thanked for recording the TEM images.
[1] M.-A. Neouze, U. Schubert, Monatsh. Chem. 2008, 139, $183-195$.

[2] P. C. Chen, S. C. Mwakwari, A. K. Oyelere, Nanotechn. Sci. Appl. 2008, 1, 45-66.

[3] N. L. Rosi, C. A. Mirkin, Chem. Rev. 2005, 105, 1547 1562.

[4] E. Katz, I. Willner, Angew. Chem. 2004, 116, 6166; Angew. Chem. Int. Ed. 2004, 43, 6042-6108.

[5] M.-C. Daniel, D. Astruc, Chem. Rev. 2004, 104, $293-$ 346.

[6] D. Astruc, M.-C. Daniel, J. Ruiz, Chem. Commun. 2004, 2637-2649.

[7] Y.-S. Shon, H. Choo, C.R. Chimie 2003, 6, 10091018.
[8] J. H. Fendler, Chem. Mater. 2001, 13, 3196-3210.

[9] A. C. Templeton, W. P. Wuelfing, R.W. Murray, Acc. Chem. Res. 2000, 33, 27-36.

[10] J. D. E. T. Wilton-Ely, Dalton Trans. 2008, 25-29.

[11] A. J. Hallett, P. Christian, J. E. Jones, S. J. A. Pope, Chem. Commun. 2009, 4278-4280.

[12] E. R. Knight, N.H. Leung, Y.H. Lin, A. R. Cowley, D. J. Watkin, A. L. Thompson, G. Hogarth, J. D. E. T. Wilton-Ely, Dalton Trans. 2009, 3688-3697.

[13] E. R. Knight, N. H. Leung, A. L. Thompson, G. Hogarth, J. D.E. T. Wilton-Ely, Inorg. Chem. 2009, 48, 3866-3874.

[14] E. R. Knight, A. R. Cowley, G. Hogarth, J.D. E. T. Wilton-Ely, Dalton Trans. 2009, 607-609. 
[15] C. R. Mayer, G. Cucchiaro, J. Jullien, F. Dumur, J. Marrot, E. Dumas, F. Sécheresse, Eur. J. Inorg. Chem. 2008, 3614-3623.

[16] K. G. Thomas, P. V. Kamat, Acc. Chem. Res. 2003, 36, $888-898$.

[17] K. G. Thomas, B.I. Ipe, K.P. Sudeep, Pure Appl. Chem. 2002, 74, $1731-1738$.

[18] J. Massue, S. J. Quinn, T. Gunnlaugsson, J. Am. Chem. Soc. 2008, 130, 6900-6901.

[19] C. R. Mayer, E. Dumas, F. Sécheresse, J. Colloid Interface Sci. 2008, 328, $452-457$.

[20] B. I. Ipe, K. Yoosaf, K. G. Thomas, J. Am. Chem. Soc. 2006, 128, $1907-1913$.

[21] S.-W. Lai, C.-M. Che, Top. Curr. Chem. 2004, 241, 27 63.

[22] J. A. G. Williams, Top. Curr. Chem. 2007, 281, $205-$ 268.

[23] K. M.-C. Wong, V.W.-W. Yam, Coord. Chem. Rev. 2007, 251, 2477-2488.

[24] C.-C. Kwok, S.-C. Yu, I. H. T. Sham, C.-M. Che, Chem. Commun. 2004, 2512-2513.

[25] C.-M. Che, W.-F. Fu, S.-W. Lai, Y.-J. Hou, Y.-L. Liu, Chem. Commun. 2003, 118-119.

[26] D.-L. Ma, C.-M. Che, Chem. Eur. J. 2003, 9, 6133 6144.

[27] C.-M. Che, J.-L. Zhang, L.-R. Lin, Chem. Commun. 2002, 2556-2557.

[28] K. H. Wong, M. C. W. Chan, C.-M. Che, Chem. Eur. J. 1999, 5, 2845-2849.

[29] W. Lu, M.C. W. Chan, N. Zhu, C.-M. Che, C. Li, Z. Hui, J. Am. Chem. Soc. 2004, 126, $7639-7651$, and refs. cited therein.

[30] S.-W. Lai, M. C.-W. Chan, T.-C. Cheung, S.-M. Peng, C.-M. Che, Inorg. Chem. 1999, 38, 4046-4055.

[31] S. Link, M. A. El-Sayed, J. Phys. Chem. B 1999, 103, $4212-4217$.

[32] X-RED (version 1.06), Program for numerical absorption correction, Stoe \& Cie GmbH, Darmstadt (Germany) 2004.

[33] G. M. Sheldrick, SHELXs/L-97, Programs for Crystal Structure Determination, University of Göttingen, Göttingen (Germany) 1997. See also: G. M. Sheldrick, Acta Crystallogr. 1990, A46, 467-473; ibid. 2008, A64, $112-122$.

[34] C. K. Johnson, M. N. Burnett, ORTEP-3, Rep. ORNL6895, Oak Ridge National Laboratory, Oak Ridge, TN (USA) 1996. Windows version: L. J. Farrugia, University of Glasgow, Glasgow, Scotland (U. K.) 1999.
See also: L. J. Farrugia, J. Appl. Crystallogr. 1999, 32, $837-838$.

[35] T. Weidner, F. Bretthauer, N. Ballav, H. Motschmann, H. Orendi, C. Bruhn, U. Siemeling, M. Zharnikov, Langmuir 2008, 24, $11691-11700$.

[36] U. Siemeling, S. Rittinghaus, T. Weidner, J. Brison, D. Castner, Appl. Surf. Sci. 2010, 256, $1832-1836$.

[37] D.-L. Ma, C.-M. Che, Chem. Eur. J. 2003, 9, $6133-$ 6144.

[38] J. H. K. Yip, Suwarno, J. J. Vittal, Inorg. Chem. 2000, 39, $3537-3543$.

[39] C. A. G. N. Montalbetti, V. Falque, Tetrahedron 2005, 61, 10827-10852.

[40] M. Bodanszky, A. Bodanszky, The Practice of Peptide Synthesis, Springer, Berlin, 1984.

[41] W. König, R. Geiger, Chem. Ber. 1970, 103, 788-798.

[42] G. A. Jeffrey, An Introduction to Hydrogen Bonding, Oxford University Press, Oxford, 1997.

[43] K. Donelly, J. F. Gallagher. A. J. Lough, Acta Crystallogr. 2008, C64, o335-o340.

[44] R. G. Nuzzo, D. L. Allara, J. Am. Chem. Soc. 1983, $105,4481-4483$.

[45] B. C. Barlow, I. J. Burgess, Langmuir 2007, 23, 1555 1563.

[46] A. Bilić, J. R. Reimers, N. S. Hush, J. Phys. Chem. B 2002, 106, 6740-6747.

[47] L. Stolberg, S. Morin, J. Lipkowski, D. E. Irish, J. Electroanal. Chem. Interfac. Electrochem. 1991, 307, 241 242.

[48] S. M. Aucott, H. L. Milton, S.D. Robertson, A. M. Z. Slawin, G. D. Walker, J. D. Woollins, Chem. Eur. J. 2004, 10, 1666 - 1676.

[49] U. Siemeling, F. Bretthauer, C. Bruhn, Z. Anorg. Allg. Chem. 2006, 632, 1027 -1032, and refs. cited therein.

[50] M. Brust, M. Walker, D. J. Schiffrin, R. Whyman, J. Chem. Soc., Chem. Commun. 1994, 801-802.

[51] M. J. Hostetler, J.E. Wingate, C.-J. Zhong, J. E. Harris, M. R. Clark, J. D. Londono, S. J. Green, J. J. Stokes, G. D. Wignall, G. L. Glish, M. D. Porter, N. D. Evans, R. W. Murray, Langmuir 1998, 14, 17 - 30.

[52] G. Schmid, Inorg. Synth. 1990, 27, 214-218.

[53] C.S. Weisbecker, M. V. Merritt, G. M. Whitesides, Langmuir 1996, 12, 3763 - 3772.

[54] F. Fillaux, J. P. Fontaine, M.-H. Baron, G. J. Kearley, J. Tomkinson, Chem. Phys. 1993, 176, 249-278.

[55] J. T. Young, F. J. Boerio, Z. Zhang, T. L. Beck, Langmuir 1996, 12, 1219-1226.

[56] M. K. Debe, J. Appl. Phys. 1984, 55, 3354-3366. 